\title{
An Empirical Analysis of Innovative Strategies and the Growth of Solar Energy Companies in Nairobi County, Kenya.
}

\author{
ADUNGOSI, Felister Amagarat; ODOLLO, Okoth Lawrence \\ Jomo Kenyatta University of Agriculture and Technology \\ * E-mail of the corresponding author: 1odollo70@gmail.com
}

\begin{abstract}
This study sought to establish the relationship between innovative strategies and firm growth of solar energy corporations in Nairobi county, Kenya. Specifically, the study sought to determine how: process innovation strategies, product innovation strategies, market innovation strategies and organizational innovation strategies influence growth of selected renewable energy organizations in Nairobi county. The study was anchored on three theories; resource-based theory, dynamic capabilities theory, and the diffusion of innovation theory. The study adopted explanatory research design targeting all the 34 renewable energy companies licenced by the Energy and Petroleum Regulatory Authority to exclusively deal in solar consumer devices. As the population was small, census survey was adopted. Primary data was collected through structured questionnaires formulated on a fivepoint Likert -type scale. The questionnaire was pilot tested in ten renewable energy companies that did not deal exclusively with consumer products. To ensure reliability of the study used Cronbach's Alpha coefficient. The data was analysed using descriptive and inferential statistics with the aid of Statistical package for Social Sciences (SPSS). Findings of the study indicated that innovative strategies positively influenced firm growth.
\end{abstract}

Key words: Innovation, Market, Renewable energy, Solar energy, Firm Growth

DOI: $10.7176 / \mathrm{EJBM} / 12-30-11$

Publication date:October $31^{\text {st }} 2020$

\section{Introduction}

Innovative strategies are plans to grow the market share of an organization while maximizing shareholders wealth by developing product lines in the market or process improvement targeted at satisfying customers efficiently and effectively (Reguia, 2014). For the certainty of a firm's growth and survival, its paramount that any business to be innovative and this has changed the way companies carry out business and how customers acquire goods and services. In this regard, innovativeness is viewed as an attempt to research something new that is non-existent hence it is a firm's strategic choice swayed by environmental opportunities or an administration of knowledge to generate new knowledge (Mutunga, Minja, \& Gachanja, 2014).

According to Corsino (2011), innovation is a powerful factor behind differences in firms' performance, with companies that innovate successfully prospering at the expense of their less able competitors. To be successful over a long period of time, firms must be able to innovate and profit from the innovations (Corsino, 2011). Different endowments of innovation capabilities and different degrees of efficiency in the search for innovations will eventually lead to persistent differences in performances of competing firms. Innovative Strategies help a company in three ways, exciting its customers, outperforming competitors, and building a new product portfolio(Corsino, 2011). Thus, firms must continue to innovate so that they meet the ever-changing consumer needs while at the same time developing new competitively priced products to migrate consumers away from highcost systems. Radical innovation is process, product or service with either unprecedented performance characteristics or known features that offer potential for significant improvements to the product. It creates a sudden change in processes, products, or services that they transform existing markets or industries, or create new ones(Ringberga, Markus, \& Rydén, 2018).

An innovation strategy can be viewed as a plan to increase market share and maximize return on investments by developing new products and services through process improvement so that organizations can effectively and efficiently satisfy the diverse customer needs. Innovative firms promote innovation in the work place by constantly putting in place employees developing programs and trainings(Abiodun, 2017). These programs are aimed at developing employees to be better by gaining new knowledge and skills. Given that the business environment is characterized by uncertainty and unpredictable, successful firms need to deal with these dynamic environmental challenges with a proactive approach and the best way to stay proactive is by being innovative. 
In the context of strategic management, businesses adopt in novative strategies aimed at meeting the desires of an organization and its stakeholders at the same time, sustaining, protecting and enhancing the natural and human resources that was required at a future date is what is termed as firm growth(Falle, Rauter, Engert, \& Baumgartner, 2016). As such managers focusing on sustainability must identify and retain resources that are key to the productivity of organization and such strategies include building good and sustained relationships with key employees and partners (Garza, 2013).

When implemented, innovation strategies are designed to develop n ew product lines, outperform competitors in the market by exciting existing customer base(Abiodun, 2017). The general goal of an innovation strategy is to come up with a new lifecycle and develop a new product which will eventually end the lifecycle of the similar existing product in the market. Through innovations firms are able to outperform other competitors by overturning other firm`s competitive advantage(Mutunga, Minja, \& Gachanja, 2014).

A firm which embraces process innovation is meant to develop products at minimized costs but offer the same or improved quality. Product innovation is a new technology commercially meant to be deployed in the market to satisfy market needs. Firms with latest technologies have higher chances of doing better than the rivals when the technology is utilized well by highly competent manpower.

Different scholars have defined firm growth in different ways depending on specialization (Gupta, Guha , \& Subra, 2013). Organizations use firm growth as a yardstick to measure progress towards pre-determined goals an indication of strength and weakness in areas of operation and make decision on the future initiatives with an aim of knowing how to initiate performance improvement.

Firm's growth is dependent upon its capacity to adjust to the changing environment and the expectation of its customers. Government, stakeholders and the institutions employees demand change continuously depending on the changes in their operating environment and consequently, there is need for the organization to align its functions to the fluctuations in order to improve its performance(Serdyukov, 2017). A firm that is able to manage turbulent complex environments and is able to maintain or improve its growth, is one that will willingly embrace change in its operating environment since its management will be able to prompt discussion concerning the correct strategic measures, allow them to come up with great range of strategic alternatives and jointly better assess the feasibility of such alternatives (Kotane \& Kuzmina-Merlino, 2012).

Solar energy is a renewable energy also referred to as clean energy. It comes from natural sources or processes that are continuously replenished (REN21, 2019). Though renewable energy is often perceived as a new technology, harnessing nature's power has historically been utilized for heating, transportation, lighting, and more. Due to increased creative and cheaper ways to capture and retain wind and solar energy, renewables are becoming a more significant source of power, contributing to more than one-eighth of U.S. generation (The Natural Resources Defense Council , 2018). Renewable energy is recognized globally as a mainstream source of generating electricity for several years. The estimated share of renewables in global electricity generation was more than $26 \%$ by the end of 2018 (Motyka, 2019). This is partly because of stable policy initiatives and targets that communicate positive signals to the industry that has resulted into decreased cost and improved technologies.

Renewable energy is becoming more cost-effective compared to conventional fossil fuel fired power plants. As at the end of 2018, electricity produced from new wind and solar photovoltaics (PV) plants was more economical than energy from fossil fuel-fired plants in many places (REN21, 2019). In some areas, it was found to be more cost-effective to come up with new wind and solar PV power plants than to extend operating existing fossil fuel power plants. Nearly all countries have energy targets in place. Several jurisdictions have made their existing targets more ambitious in 2018. The number of renewable energy support policies increased again during the year, mostly for renewable electricity (Motyka, 2019).

In developing and emerging economies, distributed renewable energy systems continued to play an important role in connecting households in remote areas to electricity services. It is estimated 5\% of the population in Africa and $2 \%$ of the population in Asia has access to electricity through off-grid solar PV systems (The Natural Resources Defense Council , 2018). Kenya has significant amounts of renewable energy resources such as wind, solar, geothermal and biomass. If exploited well, these resources can have a significant impact in the country's energy supply mix. Kenya has made tremendous strives to assess wind, solar and small-hydro potential in the country. However, there is need for a comprehensive assessment, mapping and appraisal of all the renewable energy resources in the country as these have not been fully carried out in order to establish their technical and economic viability (KIRDI, 2017). 
In Africa, Kenya leads in exploiting renewable energy sources to provide energy required to complement the realization of Vision 2030 with technologies such as wind, geothermal, small-scale hydro and bio fuels (USAID Kenya, 2016). A vibrant solar energy market has developed in Kenya over the years for providing electricity to homes and institutions remote from the national grid. Solar utilization is mainly for photovoltaic (PV) systems, drying, water heating, lighting and water pumping (Elmi, 2018). The renewable energy sector has experienced several changes following the Government of Kenya intervention to advocate and promote its usage among its citizens. Some of the policy tools the government is using to stimulate renewable energy development and scalingup renewable energy supply includes tax incentives such as zero-rating Value Added Tax (VAT) and removal of import duty on renewable energy equipment and accessories (KfW Development Bank, 2014).

With a ready market, more and more firms have been licensed to manufacture and distribute appliances in the renewable energy sector A substantial number of companies have set out into the renewable energy sector in Kenya aimed at taking advantage of the Government's policy on increasing the production and usage of renewable energy(KIRDI, 2017). Data from The Energy and Petroleum Regulatory Authority (EPRA) indicates that there are 34 companies dealing in consumer devices as of April 2019. This has made the solar renewable energy sector competitive because of increased number of companies as more and more entrepreneurs enter the sector. The resultant ripple effect has forced companies to devise several innovative strategies to ensure their survival. Further, some barriers exist affecting the exploitation of solar energy resource which include high initial capital costs, low awareness of the potential opportunities and economic benefits offered by solar technologies.

\subsection{Statement of the problem}

Renewable energy especially solar are taking a role in increasing importance in the energy industry. Companies are thus progressively positioning themselves for the proclaimed energy transition (Pickl, 2019). Data from International Energy Agency show that renewables accounted for close to two third of new power installations in the world in the year 2018. As claimed by BP's 2018 energy outlook, solar energy will be the fastest growing source of energy increasing five-fold by 2040 thus providing around 14\% of the global primary energy (Pickl, 2019). As a result, a vibrant solar energy market has developed in Kenya over the years for providing electricity to homes and institutions remote from the national grid (Elmi, 2018). A number of organizations have ventured into the renewable energy sector in Kenya aimed at taking advantage of the government's policy on increasing the production and usage of renewable energy (KIRDI, 2017).

With increased number of companies dealing in consumer devices, micro-solar kits have been widely disseminated in urban and rural areas contributing to $26 \%$ of rural electrification and access to clean energy. Despite the increasing adoption of solar PV products by consumers coupled with the attraction of a large number of market players, the sector has become very competitive due to increased number of companies and entrepreneurs joining in for a piece of the pie (KIRDI, 2017). If left unchecked, existing companies bottom line will be wiped out with the resultant ripple effect affecting firm's growth. As a result, companies have been forced to devise several innovative strategies to ensure their survival.

\section{$2 \quad$ Literature Review}

\subsection{Theoretical Review}

Theoretical review clarifies and explains the systematic association of study constructs with a key aim of explaining, predicting and controlling such phenomenon (Odollo, Iravo, \& Sakwa, 2018). This study was anchored in three theories, the Resource Based Theory, Dynamic Capabilities Theory, and diffusion of innovations theory. The current study adopts multiple theoretical approach as opposed to a single theory as multiple theories support a clearer understanding of the study variables. This is in line with Odollo et al. (2018) who supported the integrated theoretical approach.

The Resource Based Theory (RBT) of the firm, was postulated by Penrose in 1959, underscores the role of innovation which are seen as resources and capabilities in forming the basis of firm growth. The resource-based approach perceives firms with superior systems and structures being profitable not because they engage in strategic investments that may deter entry and raise prices above long run costs, but because they have markedly lower costs, or offer markedly higher quality or product performance (Breznik \& Hisrich, 2014). Such firms are hence in a better position to implement strategies. This approach centres on the rents accruing to the possessors of scarce firm-specific resources rather than the economic profits from product market positioning.

The Resource Based Theory is seen as having huge potential as a theory in the field of firm growth (Abdalla , 2014). The theory seeks to explain the internal sources of a firm's Sustained Competitive Advantage (SCA) .Its central proposition is that if a firm is to achieve a state of SCA, it must acquire and control valuable, rare, 
inimitable, and non-substitutable resources and capabilities, plus have the organization in place that can absorb and apply them (Barney, 1991).

The RBT evaluates and classifies a firm's strategic advantages cantered on probing its distinctive mixture of assets, skills, capabilities, and intangibles of an organization (Pearce \& Robinson, 2012). Accordingly, the RBT fundamental premise is that organizations differ in a big way because each holds a distinctive package of resourcestangible and intangible assets and organizational capabilities to make use of those assets. Each organization develops proficiencies from these resources, and when advanced especially well, this becomes the source of the firm's competitive advantages (Pearce \& Robinson, 2009). Innovation influence firm growth through the intervening effect of resources (Ombaka, Machuki, Awino, \& Wainaina, 2015).

The RBT emerged as a way to make the core competences concept more focused and measurable creating better means of implementing strategy (Pearce \& Robinson, 2007). Fundamental to the RBT's ability to do this is the demarcation of three basic resources, some of which may become the building slabs for distinguishing competences in strategy implementation. These resources, according to Pearce and Robinson, (2009), includes tangible assets and intangible assets. While tangible assets have physical attributes, intangible assets don't. Both types of resources, however play an important role in strategy implementation. The main propositions of this theory that resources possessed by an organization have an influence on firm growth are the anchoring postulation of this study.

The Dynamic Capability Theory which is an extension of the resources-based theory was put forward by Teece, Pisano and Shuen in 199. Dynamic capabilities are the firm's ability to integrate, build, and reconfigure internal and external resources to address rapidly changing business environments. Dynamic capabilities are an organization's skills to reintroduce and recreate its strategic resources to meet the requirements of fluctuating environment (Johnson, Scholes, \& Whittington, 2017). Dynamic capabilities are an organization's way of continuously assimilating, reconfiguring, renewing and recreating its resources and capabilities, and most significantly, upgrade and reconstruct its key resources as business environment changes to ensure its strategy is implemented(Wang \& Ahmed, 2007). Capabilities relate to an organization capability to deploy resources, usually in combination, and encapsulate both explicit processes and those tacit elements (such as know-how and leadership) embedded in the processes.

Hence, capabilities are often specific to an organization and are developed over time through complex interactions among the firm's resources(Abiodun, 2017). Dynamic capabilities thus reflect an organization's ability to achieve its competitive advantage and most importantly implement its strategy. Dynamic capabilities may be relatively formal or may take the form of strategic move by which new skills are learned by the organization (Johnson, Scholes, \& Whittington, 2017). The DCT posit that an organization's ability to achieve innovative forms of competitive advantage depends on path dependencies and market positions (Ombaka, et al., 2015).

The DCT has as its main premise the capacity to renew resources and capabilities to achieve congruence with a changing business environment (Breznik \& Hisrich, 2014). Organizations have differential abilities in deploying and configuring their resources (e.g. patents, marketing knowledge, brands etc.). These abilities are termed "capabilities" which are themselves idiosyncratic to the firm, being based on firm heuristics, experiential learning and, to a limited extent, imitation (Pisano \& Teece, 2011). Resources are acquired in factor markets or developed internally. The diffusion of innovation theory by Rodgers (2003) explains how, why and what rate new iinovative ideas spreads. Diffudion is the process in which an innovative idea is commmunicated to the particpants over time.

The spreading of an innovative idea, also known as diffusion, takes place within a particular section of the population. The resultant effect of the diffuision process is people being part of the new ideas, behaviours or the new products arising from the innovation process. Rodgers (2003) argues that for innovation to be a success, and support firm growth, the rate of usage is important. In addition, diffudsion is influenced by relative advantage, compresity, triability and observability. The theory is relevant to this study as the rate of innovativeness and its usage is fundamental to firm growth. The theory informs all the variables.

\subsection{Conceptual Framework}

A conceptual framework is a set of broad ideas and principles taken from relevant fields of enquiry and used to structure a subsequent presentation (Saunders, Lewis, \& Thornhill, 2015). The schematic diagram 2.1 guided the study and showed the interrelationship among the key study variables. 


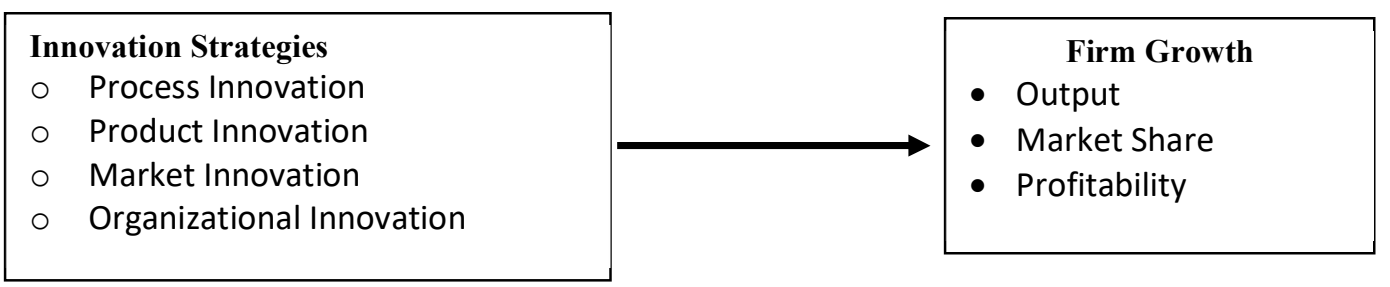

Figure 2.1: Conceptual framework depicting relationships among study variables

\subsubsection{Process Innovation Strategies}

Process innovation strategies are used by firms to adjust to the variations and changes in the business environment. It therefore involves building on the capabilities of the organization with an aim of creating new products and services. The process of innovation will therefore involve building on the capabilities of the organization geared towards creating new products and services (World Economic Forum, 2015). Process innovation strategies thus lead to creation new product and services and offering them to the market., and as Rosli and Sidek (2013) intone, process innovation strategies involves introduction of a new methods of production. It includes new procedures, policies, organisational forms and knowledge embodied in products, distribution channels, applications as well as customer expectations, preferences and needs (Rosli \& Sidek, 2013). Such innovations can involve significant changes in the equipment and software used in services-oriented firms or in the procedures or techniques that are employed to deliver services. Process innovations are intended to decrease unit costs of production or delivery, to increase quality, or to produce or deliver new or significantly improved products (OECD, 2004).

A study by Varis and Littunen (2010) examined relationship between process and firms' performance of small and medium enterprises in Finland, using quantitative research design, and used questionnaires as the data collection instrument. The study findings indicated that process innovations were directly associated with firms' growth. Further, the study did not indicate positive relationship between process innovation and firms' profitability(Varis \& Littunen, 2010). Abdilahi, Hassan, and Muhumed (2017) Investigated the impact of process innovation on the performance of Small and Medium Enterprises (SMEs) in Hargeisa, Somaliland. The study variables were grounded on the open innovation theory, and adopted quantitative research design and collected data from a population of 6930 SMEs out of which sample of 378 SMEs was selected using stratified random sampling technique. The study used regression analyses to estimate the influence of process innovation on performance. The regression results of the study revealed that process innovation significantly affected the performance of SMEs in Hargeisa.

Vasconcelos and Oliveria (2018) sought to identify and measure the impact of the types of innovation on micro and small enterprises' performance in the foodservice industry during the period 2015/16. A sample of 55 micro and small enterprises located in the Pernambuco in Brazil were considered for the purpose of the analysis. The innovations developed by the firms were identified and measured using the sectorial innovation index, and the firm's performance was calculated by the annual revenue. The impact of the innovations on performance was measured using multiple linear regression and quantile regression. The regressions' findings suggested that two innovation dimensions stand out concerning firm performance, that is, brand and customer experience are thought as to contribute to firm performance significantly. However, it has also been found that the contribution of the innovations may vary in the level of firm performance.

\subsubsection{Product Innovation Strategies}

Product innovation strategies are plans designed for introducing new products with the aim of attracting new customers and thereby creating new market opportunities can also be seen as the process of introducing fresh goods and services with the point of pulling in new clients and therefore creating new markets. Product innovation strategies are about technical designs of the product specifications, research and development activities and marketing the new products through commercial activities (Abiodun, 2017). Product innovation is critical to a firm as it enhances and ensures the firm stays focused and aware of its competitive environment. This ensures that the firm is able to introduce new products into the market hence gaining competitive advantage. Product innovation 
strategies thus ensure that the organization is able to protect itself from the competitor threats (Atkinson \& Mengher, 2014). There exists a significant relationship involving organizational accomplishments and positive product innovation. The process of Innovation will therefore involve building on the capabilities of the organization geared towards creating new products and services. Process innovation strategies thus are ideas creation strategies that eventually lead to creation of new product and services and offering them to the market. Introducing new products to the market is an important way by which organizations adapt or respond to increasing global competition, rapidly changing customer demands, technological advancements, and shorter product life cycles (Brown \& Eisenhardt, 2009).

Developing new products is of the highest importance for the survival of firms. This not only refers to really new products, but firms also need to invest in modifying their existing products. Entrepreneurs embrace product innovations in order to respond to changes in market demand or to improve organization efficiency (Maulana, 2016). Product innovation is one of the sources of firm competitiveness that can be applied to improve the quality of products leading to improved firm performance and competitiveness (Sidek \& Rosli, 2013). Product innovation also provides a variety of choice of a firm's products to the customers and greater perceived value as compared to the old products (Crawford et al., 2003).

Oke, et al. (2007) carried out a study on firms in the UK and concluded that product innovation had a positive impact on firm performance. Atlay, Anafarta and Sarvan (2013) in their study on firms in the automotive supplier industry in Turkey concluded that product innovation had a positive significant impact on firm performance. Belderbos, Duvivier and Wynen (2010) carried out a study on innovation and Export competitiveness in Flemish firms by examining the effect of innovation on export intensity and growth using both cross-sectional and panel data of 733 firms. The study concluded that the implementation of innovations especially product innovations had a robust positive correlation with export intensity of firms. Moreover, a study by Sidek and Rosli (2013) on the impact of Innovation on the performance of Small and Medium Manufacturing Enterprises in Malaysia using a sample of 284 SMEs. Research findings indicate that product innovation influenced firm performance positively.

A study by De-Loecker (2011) on product differentiation established that company differentiates their products so as to expand the lifecycles of current products in the market or to leverage on benefits that accrue from the brand name of reputation. Product differentiation strategy entails modifying the current products or creating new but related and similar products for marketing to current customers by the help of already established channels. Product differentiation attracts satisfied clients to new products due to their direct experience with offering of the firm. This study did not indicate the context it was carried out where the current study is on renewable energy firms in Kenya.

Jayani, (2018) posit that innovation may be in product uniqueness, brand image, superior quality or in leadingedge products and services designed to fit the changing needs of customers and creates a positive relationship between innovation and growth. On their part, Mutunga, Minja, and Gachanja, (2014)) indicated a positive effect on organizational performance measured by Return on Assets (ROA). Furthermore, for new products or services to be successful in the market, they should carry superior quality- implying a positive mediation effect of quality on the relationship between innovativeness and market success. Through structural equation modelling, innovativeness mediates the relationship between quality and growth, while quality mediates innovativeness and profitability and innovativeness and quality both have a mediation effect on market value. Both profitability and growth have a mediation effect on market value (Abiodun, 2017).

\subsubsection{Market Innovation Strategies}

Market innovation strategies relates to utilization of the promotion mix with an aim of fulfilling clients' needs. Firms should attach importance to market innovations as there are enablers of faster and more efficiently service to clients. Marketing innovation strategy is defined as the generation and implementation of new ideas for creating, communicating, and delivering value to customers and managing customer relationships (Dragisa \& Dragan , 2016). The ultimate goal of market innovative strategy is the discovery of better, new potential and ready markets, attending to them in an improved or new way in order to maximize the market share and ultimately attaining firm growth. Marketing innovation is the employment of a fresh promotion technique that comprises substantial deviations in product design or packaging, product placement, product promotion or pricing (OECD, 2005).

A study by Otero-Neira et al. (2009) on innovation and performance in SME industries found strong evidence that market innovation positively influenced business performance. Similarly, a study by Varis and Littunen (2010) on SMEs in Finland confirmed a robust significant relationship between marketing innovation and firm performance. 
However, a study by Sidek and Rosli (2013) on the impact of Innovation on the performance of Small and Medium Manufacturing Enterprises in Malaysia concluded that marketing innovation did not have significant effects on firm performance.

Kirtiş and Karahan (2011) examined whether social media firms had strong cost efficiency as compared to other firms. The study found out that the operational functions of an organization is to achieve performance i.e. productivity. A major concern of most businesses is future survival and prosperity. Coming up with innovative ways of marketing the products of the company helps an organization to gain competitive advantage over its competition. The study further revealed that social networking media and platform are now commonly applied.

A study by Cheng and Krumwiede (2012) on the role of service innovation in the market orientation new service performance linkage noted that market innovation pays special attention towards the improvement of the present markets mix, hence potential markets are readily recognized in conjunction with the provision of new ways that are meant to serve target markets. The study findings revealed that firms employ market segmentation techniques whereby they divide their target markets into special segments while paying regards to their dissimilar characteristics. This serves to ensure optimal firm productivity since the needs of the diverse market segments are addressed in across the diverse markets. However, innovations need more effort and thorough analysis during planning since high costs are involved and at times risk failure is simply too high. Nevertheless, successful implementation of innovation translates to greater rewards in terms of better organizational performance due to efficiencies and cost reduction synergies attained (Cheng \& Krumwiede, 2012).

Moreover, Naidoo (2010) examined interrelationships] between innovations, marketing orientation, strategic competitive advantage in view of the performance of an organization. From the findings, marketing orientation had significant effect on marketing innovation and this affected competitiveness positively. The study concludes that marketing innovation had a positive correlation with performance of the firm. Witell, Gustafsson and Kristensson (2012) assessed how customer creation affected innovation. The study was done in communication sector. From the findings, customer orientation significantly affected innovation in the service sector and this resulted into positive effect to the market performance of the firm.

\subsubsection{Organizational Innovation Strategies}

According to Corsino (2011), innovative strategies relate to how new ways of workings can be structured to ensure an organization attains its goals. Organizational innovation strategy can either be a new product, a new technology, or a new administrative process. In addition, organization innovation strategy is defined as the process a firm creates and defines problems and then actively develops new knowledge to solve them. In that respect, organizational innovation encompasses product innovation, process innovation, and marketing innovation (Dragisa \& Dragan , 2016).

In this century, globalization and knowledge economies, organizational innovation is a critical ingredient in advancing economic performance of firms. Organisational innovation involves the implementation of new organisational methods in the firm's business practices, workplace organisation or external relations (OECD, 2005). These include the implementation of new methods for organising procedures and routines for the conduct of work, introduction of management systems, business re-engineering, lean production, and quality-management system, implementation of new methods for allocating responsibilities and implementation of new ways of improving relations with external firms /institutions (OECD, 2005).

Organisational methods are intended to improve a firm's performance by reducing administrative/transaction costs, improving workplace satisfaction, gaining access to non-tradable assets (such as non-codified external knowledge) or reducing costs of supplies (OECD, 2005). A study by Mensah and Acquah (2015) on the effect of innovation types on the performance of SMEs in Takoradi metropolis revealed a positive significant relationship between organizational innovation and firm performance.

\section{Research Methodology \\ 3.1 Research Design}

According to Cooper and Schindler, (2013) research design is a map for the collection, measurement and analysis of data. This study adopted explanatory research design. Explanatory research design measures the extent of relationships, the nature of the functional relationship between different sets of variables.

\subsection{Target Population}

The target population is the entire set of units for which the survey data are to be used to make inferences. Therefore, the target population describes those units for which the results of the survey are meant to generalize 
(Saunders, Lewis, \& Thornhill, 2015).The target population of this study comprised all the 34 renewable energy companies licenced by the Energy and Petroleum Regulatory Authority as of April 30, 2019 to deal in exclusively in solar consumer devices.

\subsection{Sample and Sampling Technique}

The study adopts census survey as this captured the variability of responses from all the energy companies in Nairobi. In addition, this facilitates comparative analysis as well as adequate representation, accuracy and reliability. This included all thirty-four solar energy companies licenced by the Energy and Petroleum Regulatory Authority (EPRA) as of April 30, 2019 to deal in exclusively in solar consumer devices. The study purposively targeted production, marketing managers and the managing director of these solar energy companies.

\subsection{Data Collection Instruments}

The study used structured questionnaires to collect primary data. Primary data entails collection of information for the first time and it will be done through the use of structured questionnaires. A questionnaire is a pre-formulated written set of questions to which the respondents record the answers usually within rather closely delineated alternatives. The questionnaire was formulated on a five-point Likert -type scale. The questionnaire items were generated from previous empirical literature, theory and the researchers own context-based questions.

The questionnaire captured information on the variables and was divided into three sections, A, B and C. Part A captured general information of the respondents, section B captured information on innovative strategies divided into independent variables which are product innovation strategies, process innovation strategies, organization innovation strategies and market innovation strategies., while part $\mathrm{C}$ covered information on firm growth. The questionnaires were administered through drop and pick technique to the respondents.

The target respondents were senior managers of renewable energy companies licenced to deal in exclusively in solar consumer devices. The study purposively targeted production and marketing managers who are in the best position to answer the research questions as they were taken to have enough information and are able to give directions for the organization. They were thus deemed to be in a position to provide credible responses. Senior managers are involved in strategic planning and execution at the corporate level and are therefore best placed to answer the research questions. They were also deemed to be able to give information that is reliable, objective and consistent that is needed for the rigor of this research.

\subsection{Pilot testing}

Pilot testing is a small-scale trial, which is intended to assess the adequacy of the research design and of instruments to be used for data collection which is a small-scale version or trial run of the major study (Mugenda, 2009). To conduct an effective study, the sample for pilot study must be representative of the variety of individuals that the main study intends to cover. Following a recommendation by Kothari (2004) of 10 to 30 respondents to pilot study in survey research, the study questionnaire was piloted in ten renewable energy companies that don't deal exclusively with consumer products randomly selected prior to data collection to establish if the respondents can answer the questions without difficulty. Pilot testing helped verify the effectiveness of the instruments by determining validity and reliability of the study instruments. The feedback was used refine the study tools (Mugenda, 2009).

\subsubsection{Validity Test}

Validity refers to the degree to which research instrument measures what it is supposed to measure (Kothari, 2013). The study incorporated criterion- related, content and constructs validities. Content validity refers to the extent to which research instrument provides adequate coverage of the topic under study. It is determined by subjecting the instrument to a panel of experts (supervisors) to assess whether it captures all the required information of study variables as guided by the conceptual framework constructs of the study. Therefore, when properly evaluated, content validity is considered to be good if the instrument contains a representative sample of the universe (Kothari, 2013).

On the other hand, criterion-related validity relates to the researcher's ability to predict some outcome or estimate the existence of some current condition. This is expressed as the coefficient of correlation between test scores and some future performance(Kothari, 2013). To achieve criterion-related and validity, the study proposes to use correlation coefficients so as to determine the inter-variable correlation amongst and between the study variables. Lastly, construct validity is considered as the degree to which a test measures what it claims or purports to be measuring (Kothari, 2004). In other words, it testifies how well the results obtained from the use of the measure fit the theories around which the research is designed. This is achieved by ensuring that the questionnaire items 
are picked from conceptual framework constructs. This shall ensure comprehensiveness of the item. Besides, the study shall utilize the theoretical underpinning to justify the theoretical framework variables.

\subsubsection{Reliability Test}

Reliability is the consistency of a set of measurement items(Cooper \& Schindler, 2013). Reliability ensures that results can be replicated either by another study or in another sector and still get the same results. The study used Cronbach's Alpha coefficient $(\alpha)$ of internal consistency that indicates the extent to which a set of test items can be treated as measuring a single latent variable. The recommended and accepted minimum value of 0.7 was used as a cut-off (Mugenda, 2009). Items that did not meet the condition were either dropped from the study or refined to meet the criteria.

\section{6 Data Processing and Analysis}

Data processing refers to conversion of raw data to meaningful information. In this study, the responses from the respondents were edited, classified, coded and tabulated. The study used quantitative techniques in analysing the data(Cooper \& Schindler, 2013). Quantitative data was analysed both descriptively and inferentially using Statistical Package for Social Science (SPSS) Version 23. Information was presented in form of descriptive statistics and included frequency distribution, mean scores standard deviations; and one sample t-tests for comparisons.

\subsubsection{Correlation Analysis}

Correlation analysis was employed to establish the relationship between innovative strategies and the firm's growth. Pearson correlation coefficient (r) was used to show the extent of correlation between study variables and the strength of the linear relationship (Cooper and Schindler, 2006).

\subsubsection{Regression Analysis}

The study adopted a multiple regression model (MRM) to establish the relationship between Innovative Strategies and the growth of solar energy companies. Coefficient of determination $\left(\mathrm{R}^{2}\right)$ was used to shows the proportion of variance in the dependent variable accounted for by the combination of predictors(Mugenda, 2009). Multiple regression analysis was performed at 95 percent confidence level and the regression model is presented in equation 1.

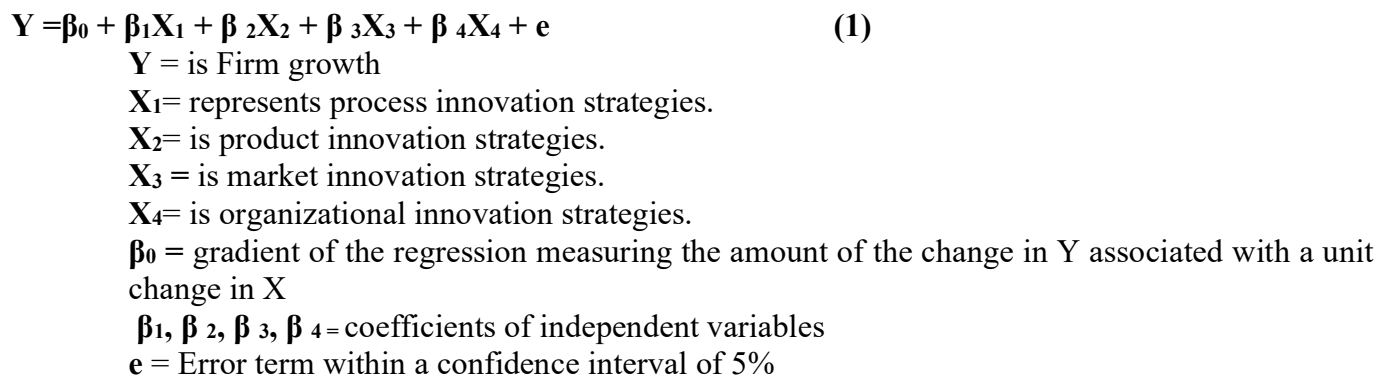

\section{Research Findings and Discussion}

\subsection{Response Rate}

Out of the 68 questionnaires that were distributed to the respondents, 64 were collect filled and successfully returned, 2 were returned but incomplete and another 2 were not returned. Only correctly filled questionnaires were used in the analysis. This information is presented in Table 4.1.

Table 4.1 Response Rate

\begin{tabular}{lcc}
\hline Questionnaires & Frequency & Percent \\
\hline Returned and correctly filled & 64 & 94 \\
Returned but incomplete & 2 & 3 \\
Unreturned & 2 & 3 \\
Total & $\mathbf{6 8}$ & $\mathbf{1 0 0}$ \\
\hline
\end{tabular}

Findings in Table 4.1 indicated that response rate was 94 percent. Saunders, Lewis and Thornhill (2015) argues that a response rate of over 80 percent is very good. The response rate in this study was therefore considered sufficient for conducting data analysis and drawing inferences, conclusions and recommendations. 


\subsection{Reliability Analysis}

Cronbach's coefficient Alpha was used to determine the reliability of the questionnaire. Kothari (2013) argue that the higher the coeeficient, the more reliable the mearsurement scale, however if the value is too low, either few items were used or the items had little in common and suggests that a value of 0.7 was sufficient. For the purpose of this study, the alpha co-efficient was set at 0.7 and the results are presented in Table 4.2.

\begin{tabular}{|c|c|c|c|}
\hline Variable & No of items & $\begin{array}{l}\text { Cronbach's } \\
\text { Alpha }\end{array}$ & Conclusion \\
\hline Process innovation Strategies & 6 & 0.787 & Reliable \\
\hline Product Innovation Strategies & 7 & 0.735 & Reliable \\
\hline Market Innovation strategies & 7 & 0.765 & Reliable \\
\hline Organizational innovation strategies & 5 & 0.823 & Reliable \\
\hline Firm Growth & 4 & 0.813 & Reliable \\
\hline Overall for all items & 29 & 0.912 & Reliable \\
\hline
\end{tabular}

The Cronbach's Alpha results in Table 4.2 indicates alpha values of $0.787,0.735,0.7665,0.823,0.813$ and 0.912 are more than the recommenced threshold of 0.7 indicating that the questionnaire was reliable.

\subsection{Respondents' Demographic Characteristics}

The respondents' characteristics were analysed in terms of the period served with the firm, period in the current position and the highest academic qualification attained. Length of service in the current position was important as it showed that the respondent had interacted with the firm long enough and were capable of giving credible responses. Table 4.3 shows the distribution of the respondents' length of service in the current position

\begin{tabular}{lcc} 
Table $\quad$ 4.3 & Number of Years Worked in The Current Position & \\
\hline Period & Frequency & Percent \\
\hline Below 5 Years & 22 & 34.4 \\
6 - 10 Years & 11 & 17.2 \\
11 -15 Years & 14 & 21.9 \\
$16-20$ Years & 12 & 18.8 \\
Over 20 Years & 5 & 7.8 \\
\hline Total & $\mathbf{6 4}$ & $\mathbf{1 0 0 . 0}$ \\
\hline
\end{tabular}

The results in Table 4.3 indicates that majority of the respondents, 65.6 percent had worked in the current position for at least five years. Length of service has been associated with experience. Thus, the respondents were deemed to be authoritative and could give relevant information which was up to date. The study's respondents were thus in a good position to give reliable information. The study sought to establish the respondents' length of service in the fir and the results are shown in Table 4.4.

Table 4.4 Length of service in the Firm

\begin{tabular}{lcc}
\hline Period & Frequency & Percent \\
\hline Below 5 Years & 8 & 12.5 \\
$6-10$ Years & 10 & 15.6 \\
$11-15$ Years & 10 & 15.6 \\
$16-20$ Years & 6 & 9.4 \\
Over 20 Years & 30 & 46.9 \\
\hline Total & $\mathbf{6 4}$ & $\mathbf{1 0 0 . 0}$ \\
\hline
\end{tabular}

From the results in Table 4.4, 87.5 percent of the respondents had worked for their respective firms for terms exceeding 5 years. The study also sought to establish the highest level of education attained by the respondents and the results are shown in Table 4.5. 
Table 4.5: Highest Level of Education

\begin{tabular}{lcc} 
Level of Education & Frequency & Percent \\
\hline Diploma Level & 4 & 6.3 \\
Bachelor's degree level & 39 & 60.9 \\
Master's degree level & 17 & 26.6 \\
Other & 4 & 6.3 \\
\hline Total & $\mathbf{6 4}$ & $\mathbf{1 0 0 . 0}$ \\
\hline
\end{tabular}

The results in Table 4.5 indicates that 60.9 percent of the respondents had a bachelor's degree, which means that the study's respondents were highly educated. This implies that the employees have been exposed to diverse idea that might enhance firm growth.

\subsection{Descriptive Statistics}

To establish the extent to which innovative strategies influenced firm growth, the respondents were asked to give their opinion on a series of statements that were based on study objectives. The statements were in five-point Likert scale whereby when combined would measure the respondents' opinion on the contribution of innovative strategies toward the growth of solar energy companies in Kenya. The researcher calculated the mean and the standard deviation of the Likert scale items and obtained the average for each of the objectives. The range of each point in the scale was obtained by dividing the difference between the highest and the lowest points with the number of points in the scale $[(5-1) / 5=0.8]$. Therefore, mean scores 1 to 1.8 represented "to no extent", 1.81 to 2.6 represented to "less extent", 2.61 to 3.4 represented "moderate extent", 3.41 to 4.2 represented "large extent" and mean score above 4.21 represented a response of "strongly agree". The results are discussed in the subsections that follows.

\subsubsection{Process Innovative Strategies}

Process innovative strategies are used by firms to adjust to the variations and changes in business environment. They were operationalized as automation of processes, process management and process design. The respondents were asked to indicate the extent to which various statements on process innovative strategies were applicable in their firms and the results are shown in Table 4.6.

Table 4.6: Process Innovative Strategies

\begin{tabular}{lccc}
\hline Statement & Mean & SD & CV \\
\hline $\begin{array}{l}\text { Our company management holds meetings to discuss new process } \\
\text { innovations regularly }\end{array}$ & 3.73 & 1.03 & 0.28 \\
$\begin{array}{l}\text { The firm sources its supplies from regions that are known for } \\
\text { superior quality. }\end{array}$ & 3.30 & 1.11 & 0.34 \\
$\begin{array}{l}\text { Business Process Re-engineering is adopted } \\
\text { The firm has installed superior and robust processing system. }\end{array}$ & 2.72 & 1.08 & 0.40 \\
$\begin{array}{l}\text { The firm reviews its operating processes regularly } \\
\text { The firm has developed new channels for products and services } \\
\text { offered. }\end{array}$ & 3.66 & 1.30 & 0.45 \\
Average & 3.48 & 1.08 & 0.30 \\
\hline
\end{tabular}

The results in Table 4.6 indicates that overall mean score for the six statements used to measure process innovative strategies was 3.30. This implied that process innovative strategies applied to a moderate extent in solar firms in Nairobi county in Kenya. Overall coefficient of variation of 0.34 implied low variability of the responses meaning that the respondents' opinion with regard to process innovative strategies was consistent. The statement "our company management hold meetings to discuss new process innovations regularly" had the highest mean score $(3.73$; coefficient of variation $=0.28)$. This revealed that to a large extent, regular meetings to discuss new process 
innovative strategies were held. The statement also had the lowest variability indicating that respondents were in agreement with the assertion. The statement with the highest variability was superior and robust processing systems were installed (Coefficient of variation $=0.45$ ) implying that there was disparity among the respondents on the favourability of this factor. The statement the firm revealed it processes regularly had the second highest mean score $(3.66$; coefficient of variation $=0.30)$ which corresponded to a large extent. The statement business process re-engineering had the lowest mean score $(2.72$; coefficient of variation $=0.40)$ corresponding to a moderate extent.

\subsubsection{Product Innovative Strategies}

There are plans designed for introducing new products with the aim of attracting new customers thereby creating new market opportunities. The respondents were asked to indicate the extent to which various statement applied in their firm. The results are indicated in Table 4.7.

Table 4.7 Product Innovative Strategies

\begin{tabular}{|c|c|c|c|}
\hline $\begin{array}{rr}\text { Statements } \\
\text { Sta }\end{array}$ & Mean & SD & $\mathbf{C V}$ \\
\hline The firm has introduced new products. & 4.11 & 0.69 & 0.17 \\
\hline The firm has increased product variety & 4.33 & 0.67 & 0.15 \\
\hline The firm has improved product quality & 4.06 & 0.73 & 0.18 \\
\hline The firm has shortened product cycle & 4.06 & 0.77 & 0.19 \\
\hline $\begin{array}{l}\text { The firm change products to be in line with customers changing } \\
\text { preferences }\end{array}$ & 3.33 & 1.02 & 0.31 \\
\hline Our company has a policy for new product innovations & 3.80 & 0.82 & 0.22 \\
\hline We patent our new product innovations & 3.42 & 1.10 & 0.32 \\
\hline Average & 3.87 & 0.83 & 0.22 \\
\hline
\end{tabular}

The results in table 4.7 indicates that the overall mean score for seven statements used to measure product innovative strategies was 3.80. This implied that product innovative strategies applied to a large extent to solar energy companies in Nairobi County. Overall coefficient of variation of 0.23 indicated low variability in the responses meaning that the respondents' opinion with regard to product innovative strategies was consistent. Improved product variety had both the highest mean score and the lowest coefficient of variation $($ Mean $=4.33$; coefficient of variation $=0.15$ ). This revealed that improved product quality was more favoured more so to a very large extent compared to other factors and that there was agreement among the respondents as evidenced by the low coefficient of variation. The statement with the second highest mean score was firms having introduced new products (mean score $=4.11$; coefficient of variations $=0.17$ ) corresponding to a very large extent. Equally, the statement had the second lowest coefficient of variation indicating consensus amongst the respondents. The statement with the lowest mean score was the firms sourced it supplies from superior quality sources (mean score $=3.30$ ) corresponding to a moderate extent. The statement also had the highest variability (coefficient of variation $=0.34$ ) indicating lack of agreement among the respondents on the extent to which the solar firms had achieved this measure.

\subsubsection{Market Innovation Strategies}

Market innovation strategies relates to utilization of the promotion mix with an aim of fulfilling clients' needs. Respondents were asked to indicate the extent to which various statements relating to market innovation strategies related to their firms. The results are presented in Table 4.8. 


\section{Table 4.8 Market Innovation Strategies}

\begin{tabular}{|c|c|c|c|}
\hline Statements & Mean & SD & $\mathbf{C V}$ \\
\hline The firm uses social media to market its products. & 3.81 & 0.83 & 0.22 \\
\hline $\begin{array}{l}\text { Partnering with new other firms have improved our } \\
\text { product distribution. }\end{array}$ & 3.73 & 0.88 & 0.23 \\
\hline $\begin{array}{l}\text { The firm has established new market segments based on } \\
\text { customers' needs. }\end{array}$ & 3.94 & 0.81 & 0.21 \\
\hline Penetration pricing strategies have improved firm growth. & 3.72 & 0.93 & 0.25 \\
\hline $\begin{array}{l}\text { Use of the mobile payment platform have aided the growth } \\
\text { of our products. }\end{array}$ & 3.19 & 1.07 & 0.33 \\
\hline $\begin{array}{l}\text { Market innovation contribute to firm penetration and } \\
\text { growth }\end{array}$ & 3.73 & 0.70 & 0.19 \\
\hline $\begin{array}{l}\text { Our firm have introduced new marketing channels in the } \\
\text { past two years. }\end{array}$ & 3.14 & 1.13 & 0.36 \\
\hline Average & 3.61 & 0.91 & 0.26 \\
\hline
\end{tabular}

The average combined score $($ mean $=3.61$; standard deviation $=0.90)$ shown in Table 4.8 suggests that the respondents expresses agreement to a large extent with regards to market innovative strategies at solar firms in Nairobi county. A coefficient of variation of 0.26 indicates low variability in responses meaning that the respondents' opinion in regard to market innovation strategies were consistent. The stamen on firms establishing new market segments based on customer needs had the highest mean score (3.94; coefficient of variation $=0.21$ ). This indicated that respondents' felt that contribution of new customized markets was more predictable to a large extent, while low coefficient of variation was an indicator that there was agreement among the respondents. The statement with lowest mean score was on firms introducing new market channel in the past two years (mean score $=3.14$ ) indicating that the respondents were in agreement albeit to a moderate extent. However, the statement had the highest variability (coefficient of variation $=0.36$ ) indicating lack of consensus among the respondents on the extent of introduction of new market channels.

\subsubsection{Organization Innovation Strategies}

The adoption of ideas and behaviour new to the firm is organization innovative strategies and relates to new ways of ensuring attainment of the firm goals and growth. To capture data on these aspects, descriptive statements derived from literature were present to the respondent on a Likert scale. The respondents were required to indicate the extent to which the statements applied to their organizations. The results are presented in Table 4.9.

Table 4.9 Organization Innovation Strategies

\begin{tabular}{|c|c|c|c|}
\hline Statements & Mean & SD & $\mathrm{CV}$ \\
\hline $\begin{array}{l}\text { We have integrated important processes and programs into our } \\
\text { business models to enable us compete with competitors } \\
\text { We have integrated the work done by service providers to improve } \\
\text { efficiency }\end{array}$ & 3.03 & 1.07 & 0.35 \\
\hline $\begin{array}{l}\text { Most of our innovations are paperless as opposed to use of paper- } \\
\text { based processes and procedures } \\
\text { Our organisation puts much emphasis on customer-centre services } \\
\text { and processes }\end{array}$ & 3.34 & 1.20 & 0.36 \\
\hline $\begin{array}{l}\text { We provide value adding products and services that meets the } \\
\text { expectations of our customers } \\
\text { Average }\end{array}$ & $\begin{array}{l}3.25 \\
\mathbf{3 . 1 7}\end{array}$ & $\begin{array}{l}1.11 \\
\mathbf{1 . 1 1}\end{array}$ & $\begin{array}{l}0.34 \\
\mathbf{0 . 3 5}\end{array}$ \\
\hline
\end{tabular}

The results in Table 4.9 indicate that the average mean score for organization innovation strategies was 3.17 which show that the respondents rated these strategies moderately. The statement that most innovation were paperless had the highest mean score (mean score 3.34; standard deviation $=1.20$ ) meaning that the respondents appreciates that the firm used less paper-based processes in favour of the paperless ones. However, the statement had a higher variability (coefficient of variation $=0.36$ ) indicating lack of consensus amongst the respondents on the assertion. 
The statement with the lowest mean score was the firms emphasised on customer centred services and processes (mean score $=2.94$ ) meaning that the firms were not customer-centric. However, the statement had the highest variability (coefficient of variation $=0.39$ ) indicating that there was disparity among the respondents to the extent to which the firms focussed on customers' needs and processes.

\subsubsection{Firm Growth}

The study sought to establish to what extent firms had achieved growth. Firm growth was operationalized as growth in total assets, market share, profitability and the extent to which the firm had expanded. To capture data in these aspects, respondents were asked to indicate to what extent the various indicators applied in their firms, and the results are presented in Table 4.10.

Table 4.10 Firm Growth

\begin{tabular}{|c|c|c|c|}
\hline Statements & Mean & SD & $\mathbf{C V}$ \\
\hline Innovative strategies have enhanced growth in total assets & 3.75 & 0.89 & 0.24 \\
\hline $\begin{array}{l}\text { Innovative strategies have improved the market share of our } \\
\text { firm }\end{array}$ & 3.64 & 0.97 & 0.27 \\
\hline Innovative strategies have enhanced the profitability of our firm & 3.91 & 0.90 & 0.23 \\
\hline Innovative strategies have promoted the expansion of our firm & 3.81 & 0.96 & 0.25 \\
\hline Average & 3.78 & 0.93 & 0.25 \\
\hline
\end{tabular}

Results in table 4.10 indicates that profitability of the firm had been enhanced by innovative strategies had the highest mean score $($ mean $=3.91$; standard deviation $=0.93$ ). A coefficient of variation of 0.23 indicated low variability in the responses meaning that the respondents' opinion with regard to impact of innovative strategies on profitability of the firms were consistent. The average combined means score of 3.78 suggests that the respondents were in agreement that innovative strategies influenced firm growth.

\subsection{Diagnostic Tests}

To ensure that assumptions of regression model were not violated, data was subjected to various diagnostic tests.

\subsubsection{Normality Tests}

Normality tests are meant to investigate if data is well modelled through normal distribution. Violation of normality results to distorted relationship and significance tests reading to unreliable inferences. The study adopted ShapiroWilk test which is appropriate for such samples. The results are presented in Table 4.11.

Table 4.11 Normality Tests

\begin{tabular}{lccc}
\hline & \multicolumn{3}{c}{ Shapiro-Wilk } \\
\cline { 2 - 4 } Variable & Statistic & df & Sig. \\
\hline Process Innovation Strategies & .963 & 64 & .510 \\
Product Innovation Strategies & .955 & 64 & .215 \\
Market Innovation Strategies & .946 & 64 & .307 \\
Organizational Innovative Strategies & .956 & 64 & .422 \\
\hline
\end{tabular}

If p-value is greater than chosen alpha level, then the hypothesis that the data came from a normally distributed population cannot be rejected. The results in table 4.11 show that all the p-values for Shapiro- Wilk $(0.510$, $0.215,0.307$ and 0.422 ) were greater than alpha level of 0.05 . This therefore indicated that the data was normally distributed with a zero mean.

\subsubsection{Multicollinearity Test}

In instances where two or more predictor variables in a multiple regression are highly correlated, then multicollinearity is said to exist. This implies that one can be linearity predicted from the other with a non-trivial degree of accuracy. As levels of multicollinearity goes up, so does the standard errors. The test for linearity is Variance Inflation Factor (VIF). A factor of 10 or more indicated harmful degree of collinearity. The findings are presented in Table 4.12 . 


\begin{tabular}{lcc} 
Table 4.12 Multicollinearity Tests & \multicolumn{2}{c}{ Collinearity Statistics } \\
\hline \multicolumn{3}{c}{ Tolerance } \\
Process Innovation Strategies & .505 & VIF \\
Product Innovation Strategies & .660 & 1.982 \\
Market Innovation Strategies & .520 & 1.514 \\
Organizational Innovative Strategies & .528 & 1.924 \\
\hline
\end{tabular}

Table 4.12 represents collinearity statistics were all the VIF are below ten indicating absence of multicollinearity among the variables of the study. This revealed that the assumption of multicollinearity was not violated.

\subsubsection{Autocorrelation Test}

The degree of correlation between values of the same variables is termed as autocorrelation. To test autocorrelation, the study adopted Durbin - Watson (DW) test. Values of DW lying between 1.5 and 2.5 indicates absence of autocorrelation. Table 4.13 presents the results.

Table 4.13 The Durbin- Watson Test

\begin{tabular}{lll}
\hline Model & D-W & Conclusion \\
\hline Innovative strategies and firm growth & 1.921 & No Autocorrelation \\
\hline
\end{tabular}

Results in Table 4.13 indicates that there was no autocorrelation as the D-W computed was within the set range.

\subsubsection{Test for Heteroscedasticity}

To test for the presence of heteroscedasticity, the macro syntax by Gwilym Pryce on Breusch-Pagan and Koenker tests can be used. The Koenker test was favoured due to the study small sample size. The results of the test are presented in Table 4.14 .

Table 4.14 Koenker Tests Statistics

\begin{tabular}{lcc}
\hline Model & Koenker test & Sig value \\
\hline Innovative strategies and firm growth & 11.790 & 0.109 \\
\hline
\end{tabular}

Results in Table 4.14 shows p-value of the model, 0.109 , being greater than the significance level of 0.05 , hence the null is not rejected. This means that data for the model is not heteroskedastic.

\subsection{Inferential Statistics}

4.5.1 Correlation Analysis

The study conducted Pearson correlation Analysis at significance level alpha $=0.05$ in order to establish the nature and significance of association between independent and dependent variables of the study. Table 4.15 presents the results.

The results in Table 4.15 indicated that process innovation strategies $(\mathrm{r}=0.525, \mathrm{p}=0.000)$, product innovation strategies $(r=0.525, p=0.000)$, market innovation strategies $(r=0.821, p=0.000)$ and organizational innovative strategies $(\mathrm{r}=0.496, \mathrm{p}=0.000)$ had a positive and significant relationship with firm growth of solar energy companies in Nairobi County in Kenya. 
Table 4.15 Correlation Matrix

\begin{tabular}{|c|c|c|c|c|c|c|}
\hline & & $\begin{array}{c}\text { Process } \\
\text { Innovati } \\
\text { on }\end{array}$ & $\begin{array}{c}\text { Product } \\
\text { Innovatio } \\
\text { n }\end{array}$ & $\begin{array}{c}\text { Market } \\
\text { Innovatio } \\
\text { n }\end{array}$ & $\begin{array}{c}\text { Organizational } \\
\text { Innovative }\end{array}$ & $\begin{array}{c}\text { Firm } \\
\text { Growth }\end{array}$ \\
\hline \multirow{2}{*}{$\begin{array}{l}\text { Process } \\
\text { Innovation } \\
\text { Strategies }\end{array}$} & $\begin{array}{l}\text { Pearson } \\
\text { Correlation }\end{array}$ & 1 & & & & \\
\hline & Sig.(2-tail) & & & & & \\
\hline \multirow{2}{*}{$\begin{array}{l}\text { Product } \\
\text { Innovation } \\
\text { Strategies }\end{array}$} & $\begin{array}{l}\text { Pearson } \\
\text { Correlation }\end{array}$ & $.372^{* *}$ & 1 & & & \\
\hline & Sig.(2-tail) & .002 & & & & \\
\hline \multirow{2}{*}{$\begin{array}{l}\text { Market } \\
\text { Innovation } \\
\text { Strategies }\end{array}$} & $\begin{array}{l}\text { Pearson } \\
\text { Correlation }\end{array}$ & $.531^{* *}$ & $.574^{* *}$ & 1 & & \\
\hline & Sig.(2-tail) & .000 & .000 & & & \\
\hline \multirow{2}{*}{$\begin{array}{l}\text { Organizational } \\
\text { Innovative } \\
\text { Strategies }\end{array}$} & $\begin{array}{l}\text { Pearson } \\
\text { Correlation }\end{array}$ & $.660^{* *}$ & $.284^{*}$ & $.505^{* *}$ & 1 & \\
\hline & Sig.(2-tail) & .000 & .023 & .000 & & \\
\hline \multirow[t]{3}{*}{ Firm Growth } & $\begin{array}{l}\text { Pearson } \\
\text { Correlation }\end{array}$ & $.525^{* *}$ & $.524^{* *}$ & $.821^{* *}$ & $.496^{* *}$ & 1 \\
\hline & Sig.(2-tail) & .000 & .000 & .000 & .000 & \\
\hline & $\mathrm{N}$ & 64 & 64 & 64 & 64 & 64 \\
\hline
\end{tabular}

**. Correlation is significant at the 0.01 level (2-tailed).

*. Correlation is significant at the 0.05 level (2-tailed).

\subsubsection{Regression Analysis}

The study further carried out a regression analysis to asserting the degree of influence of innovative strategies on firm growth of solar energy companies in Nairobi County in Kenya. The regression results are in Table 4.16.

Table 4.16 Innovative Strategies and Firm Growth

Model Summary

\begin{tabular}{|c|c|c|c|c|c|c|}
\hline Model & $\mathbf{R}$ & $\mathbf{R}^{2}$ & Adjusted R $\mathbf{R}^{2}$ & & \multicolumn{2}{|c|}{ Std. Error of the Estimate } \\
\hline 1 & $.831^{\mathrm{a}}$ & .690 & .669 & & \multicolumn{2}{|l|}{.42793} \\
\hline \multicolumn{7}{|c|}{$\begin{array}{l}\text { a. Predictors: (Constant), Organizational Innovative Strategies, Product Innovation } \\
\text { Strategies, Market Innovation Strategies, Process Innovation Strategies }\end{array}$} \\
\hline \multicolumn{7}{|c|}{$\operatorname{ANOVA}^{\mathrm{a}}$} \\
\hline Model & & $\begin{array}{l}\text { Sum of } \\
\text { Squares }\end{array}$ & df & Mean Square & $\mathbf{F}$ & Sig. \\
\hline \multirow[t]{4}{*}{1} & Regression & & & & & \\
\hline & & 24.085 & 4 & 6.021 & 32.880 & $.000^{\mathrm{b}}$ \\
\hline & Residual & 10.805 & 59 & .183 & & \\
\hline & Total & 34.890 & 63 & & & \\
\hline
\end{tabular}

a. Dependent Variable: Firm Growth

b. Predictors: (Constant), Organizational Innovative Strategies, Product Innovation Strategies, Market Innovation Strategies, Process Innovation Strategies 


\section{Coefficients $^{\mathbf{a}}$}

\begin{tabular}{|c|c|c|c|c|c|c|}
\hline \multirow[b]{2}{*}{ Model } & \multicolumn{2}{|c|}{ Unstandardized Coefficients } & \multicolumn{2}{|c|}{$\begin{array}{c}\text { Standardized } \\
\text { Coefficients }\end{array}$} & \multirow[b]{2}{*}{ t } & \multirow[b]{2}{*}{ Sig. } \\
\hline & B & Std. Error & Beta & & & \\
\hline (Constant) & -.295 & .457 & & & -.647 & .520 \\
\hline $\begin{array}{l}\text { Process } \\
\text { Innovation } \\
\text { Strategies }\end{array}$ & .078 & .098 & .081 & & .795 & .430 \\
\hline $\begin{array}{l}\text { Product } \\
\text { Innovation } \\
\text { Strategies }\end{array}$ & .112 & .140 & .071 & & .796 & .429 \\
\hline $\begin{array}{l}\text { Market } \\
\text { Innovation } \\
\text { Strategies }\end{array}$ & .886 & .127 & .704 & & 7.001 & .000 \\
\hline $\begin{array}{l}\text { Organizationa } \\
1 \text { Innovative } \\
\text { Strategies }\end{array}$ & .058 & .088 & & .067 & .667 & .507 \\
\hline
\end{tabular}

The results in Table 4.16 indicates that on overall, a strong correlation existed between independent variables and the independent as indicated by the $\mathrm{R}$ value (Correlation coefficient) of 0.831 . The coefficient of determination, $\mathrm{R}$ square value of 0.690 indicated the innovative strategies which was the independent variables accounted for 69 percent of the variation in the dependent variable, firm growth. The F statistics value of 32.880 was significant as indicated by the $\mathrm{p}$ - value $(0.000)$ which is less than 0.05 indicating that the model was fit and significant. The results showed that process innovative strategies $(\beta=0.078, p=0.430)$ had a positive influence on firm growth. This implied that a unit change in process innovation strategies contributed to a 7.8 percent improvement in firm growth. The findings also indicated that product innovation strategies $(\beta=0.112, \mathrm{p}=0.429)$ had a positive influence on firm growth. This implied that a unit change in product innovation strategies accounted for 11.2 percent increase in firm growth.

In addition, the results showed that market innovation strategies $(\beta=0.886, p=0.000)$ had a positive influence on firm growth. The implication of this findings is that a unit change in market innovation strategies contributed to 88.6 percent improvement in firm growth. Finally, the results indicated that organization innovation strategies $(\beta$ $=0.058, \mathrm{p}=0.507)$ equally had a positive influence on firm growth. The findings suggested that organization innovative strategies contributed to 5.8 percent of the firm growth of solar energy companies in Nairobi in Kenya. Therefore, firm growth of solar energy companies in Kenya can be modelled as follows:

$$
Y=-0.295+0.078 X_{1}+0.112 X_{2}+0.886 X_{3}+0.058 X_{4}+\varepsilon
$$

Where $\mathrm{Y}=$ Firm growth; $\mathrm{X}_{1}=$ process innovation strategies; $\mathrm{X}_{2}=$ product innovation strategies; $\mathrm{X}_{3}=$ market innovation strategies; $\mathrm{X}_{4}=$ organizational innovative strategies.

\section{Summary, Conclusions and Recommendations}

\subsection{Summary of Findings}

The main objective of the study was to investigate the influence of innovation strategies on firm growth of solar energy companies in Nairobi county in Kenya. This was tested using four independent variables: process 
innovation strategies, product innovation strategies, market innovation strategies and organizational innovation strategies. From the four specific objectives, four research questions were developed. The study was anchored three theories each informing one or more of the objectives. The theories are resource-based theory, dynamic capability theory, and diffusion of innovation theory. The study adopted explanatory research design and had targeted all the 34 solar energy companies that dealt exclusively in solar consumer devices and were in the register of EPRA. The study purposively targeted two senior manager in each firm that were responsible for production and marketing, yielding a targeted population to 68 . As the population was small, sampling was not required and the study adopted census survey.

The study used primary data and was collected using a self-administered questionnaire. Descriptive statistics that included mean, standard deviations and coefficient of variations, while inferential statistics of correlation and regression analyses were used to establish the nature and magnitude of the relationship between study variables. The model specifications were tested using Shapiro-Wilk tests for normality; VIF tested multicollinearity; D-W statistics were used to test for autocorrelation while Koenker statistics tested for presence of heteroscedasticity. Results from the study indicated that all the four variables had a positive influence on firm growth.

\subsection{Conclusion}

The general objective of the study was to establish the effect of innovation strategies on firm growth of solar energy companies in Nairobi County Kenya. This was tested using four independent variables: process innovation, product innovation market innovations and organizational innovative strategies. Owing to statistical findings, several conclusions were drawn.

The first objective that sought to determine the influence of process innovation strategies on firm growth of solar energy companies in Nairobi County in Kenya. On the strength of the descriptive statistics findings, the respondents concurred to a moderate extent that process innovation strategies applied to solar firms. Further, inferential statistics indicated that process innovation strategies had a positive influence on firm growth of solar energy companies in Nairobi County in Kenya. The second objective sought to establish the influence of product innovative strategies on firm growth of solar energy companies in Nairobi County in Kenya. Descriptive results indicated that the respondents were of the view that product innovation strategies applied to a large extent to solar firms. Inferential statistics on the effect of product innovation strategies had a positive influence on firm growth of solar energy firms in Nairobi County in Kenya.

The third objective of the study that sought to examine the influence of market innovation strategies on firm growth of solar energy companies in Nairobi County in Kenya. Descriptive statistics indicated that the respondents market innovation strategies applied to a moderate extent to the solar firms. Results of regression analysis revealed a strong positive influence on firm growth. The fourth and final objective sought to determine the influence of organizational innovative strategies on firm growth of solar energy companies in Nairobi County in Kenya. Results of descriptive statistics implied that the respondents concurred to a large extent that organizational innovative strategies were linked to firm growth. These finding is supported by inferential statistics that yielded positive results.

\subsection{Recommendations of the Study}

As innovative strategies are critically important to the growth of the firm, the study recommends that solar firms must take immediate steps to improve on innovative strategies by critically assessing the current innovation strategies and firm growth. In addition, solar firms should create an enabling environment that ensures full benefits $\mathrm{i}=$ of innovative strategies are realized. The study also recommends that solar firms should strive to ensure process innovations, product innovations, market innovations and organizational innovation strategies are repositioned to be more productive thus enabling firm growth.

\subsection{Suggestions for Further Studies}

Future research on the same area should consider solar firms in other counties since there might be operational differences across different regions. Further, as this study focused on solar energy companies, future studies should focus on other types of organizations.

\section{REFERENCES}

Abdalla , A. S. (2014). Factors affecting implementation of strategy in the Kenyan oil marketing industry: A case of Libya Oil Kenya Ltd. Unpublished MBA Research project, School of Business, United States International University. 
Abdilahi, M. H., Hassan, A. A., \& Muhumed, M. M. (2017). The impact of innovation on the performance of Small and Medium Enterprises (SMEs) in Hargeisa, Somaliland. International Journal of Academic Research in Business and Social Sciences Vol. 7, No. 8, 14 - 30.

Abiodun, T. S. (2017). An Examination of the Relationships Between Different Types of Innovation and Firm Performance and the Mediating Effect of Radical and Incremental Innovations on These Relationships. International Journal of Innovation and Economic Development Volume 3, Issue 5, 38-58.

Atkinson, R. D., \& Mengher, J. (2014). Competitiveness, Innovation and Productivity: Clearing up the Confusion. The Information Technology and Innovation Foundation Journal, 17 (4), 187-197.

Barney, J. (1991). Firms resources and sustained competitive advantage. Journal of Management Vol. 17 No 1 , 99-120.

Breznik, L., \& Hisrich, R. D. (2014). Dynamic capabilities vs. innovation capability: are they related? Journal of Small Business and Enterprise Development, Vol. 21 Iss 3 , 368 - 384.

Corsino, M. (2011). Product innovation and firm growth: evidence from the integrated circuit industry. Industrial and Corporate Change, Volume 20, Issue 1, 29-56.

Dragisa, O., \& Dragan, O. (2016). The role innovation on strategic orientations and competitiveness of enterprises. Ecoforum Volume 5, Issue 1 (8), 91- 96.

Elmi, M. D. (2018). Design of a Solar PV Energy System for Wajir Town, Wajir. Unpublished Master of Science Thesis submitted to Jomo Kenyatta University of Agriculture and Technology.

Falle, S., Rauter, R., Engert, S., \& Baumgartner, J. R. (2016). Sustainability Management with the Sustainability Balanced Scorecard in SMEs: Findings from an Austrian Case Study. Sustainability, 545.

Garza, F. A. (2013). A Framework for Strategic Sustainability in Organizations: A Three Pronged Approach. Journal of Comparative International Management Vol. 16, No. 1, 23-36.

Gupta , P. D., Guha , S., \& Subra, S. (2013). Firm growth and its determinants. Journal of Innovation and Entrepreneurship Vol 2: Issue 15, 1 -12.

Jayani, R. (2018). Relationship between innovation capability, innovation type, and firm perfomance. Journal of Innovation \& Knowledge 3 , 44-55.

Johnson, G., Scholes, K., \& Whittington, R. (2017). Exploring Strategy Text and Cases (11th Edition). Edinburg Gate: Pearson Education Limited.

KfW Development Bank. (2014). Project Design Study on the Renewable Energy Development for Off-Grid Power Supply in Rural Regions of Kenya. Nairobi: KfW Development Bank.

KIRDI. (2017). Accelerating pico-solar photovoltaic lighting market in Kenya. Nairobi: Kenya Industrial Research and Development Institute.

Kotane, I., \& Kuzmina-Merlino, I. (2012). Non-financial indicators for evaluation of business activity. European Integration Studies. No 5, 212 - 219.

Kothari, C. R. (2013). Research Methodology: Methods and Techniques. Telangana, India : New Age International (P) Limited.

Motyka, M. (2019). Renewable energy industry outlook. New York: Deloitte Insights.

Mugenda, O. (2009). Research methods: quantitative and qualitative approaches . Nairobi: ACTS press .

Mutunga, S. L., Minja, D., \& Gachanja, P. (2014). Innovative adaptation and operational efficiency on sustainable competitive advantage of food and beverage firms in Kenya. European Journal of Business and Innovation Research Vol.2, No.2, 32-50.

Odollo, L. O., Iravo, M. A., \& Sakwa, M. (2018). Effect of Competitive Priorities on the Operations Performance of Sugar Manufacturing Firms in Kenya. The International Journal Of Business \& Management Volume 6 Issue 3, 245 - 262.

OECD . (2004). The OECD Principles of Corporate Governance. Cedex: OECD Publications Services.

Ombaka. (2014). Resources, external environment, innovation and performance of insurance companies in Kenya. Unpublished PHD thesis, University of Nairobi.

Ombaka, B. E., Machuki, V. N., Awino, Z. B., \& Wainaina, G. (2015). Organizational Resources, Innovation and Performance of Insurance Companies in Kenya. 1st DBA-Africa Management Review International Conference (pp. 21-41). Nairobi: University of Nairobi.

Pearce, J. A., \& Robinson, R. B. (2012). Strategic Management: Formulation, Implementation and Control 12th ed. New york: McGraw-hill/Irwin.

Penrose, E. (1995). The Theory of the Growth of the Firm, Third Edition. Oxford: Oxford University Press.

Pickl, M. J. (2019). The renewable energy strategies of oil majors - From Oil to Energy. Energy Strategy Review, $1-9$.

Pisano, G. P., \& Teece, D. J. (2011). How to capture value from innovation: shaping intellectual property and industry architecture. California Management Review, 50 (1), 278-296.

Reguia, C. (2014). Product innovation and the competitive advantage. European Scientific Journal Vol.1, 140157. 
REN21. (2019). Renewables 2019 Global Status Report. Paris: REN21 Secretariat.

Ringberga, T., Markus, R., \& Rydén, P. (2018). The technology-mindset interactions: Leading to incremental, radical or revolutionary innovations. The International Journal of Marketing for Industrial and HighTech Firms, 1-12.

Rodgers, E. M. (2003). Diffusion of Innovations, 5th Edition. New York: Free Press.

Rosli, M., \& Sidek, S. (2013). The Impact of Innovation on the Performance of Small and Medium Manufacturing Enterprises: Evidence from Malaysia. Journal of Innovation of Management in Small \& Medium Enterprises, 553-569.

Saunders, M., Lewis, P., \& Thornhill, A. (2015). Research Methods for Business Students. Essex: Pearson Education Limited.

Serdyukov, P. (2017). Innovation in education: what works, what doesn't, and what to do about it? Journal of Research in Innovative Teaching \& Learning Volume 10, Issue 1, 4-33.

Teece, D. J., Pisano, G., \& Shuen, A. (1997). Dynamic Capabilities and Strategic Management. Strategic Management Journal, Vol. 18, No. 7., 509-533.

The Natural Resources Defense Council . (2018). NRDC's Annual Energy Reports. New York: The Natural Resources Defense Council .

USAID Kenya. (2016). Development of Kenya's power sector 2015-2020. Nairobi: USAID Kenya.

Varis, M., \& Littunen, H. (2010). Types of innovation, sources of information and performance in entrepreneurial SMEs. European Journal of Innovation Management, Vol. 13 Issue: 2, 128-154.

Vasconcelos , R., \& Oliveria, M. (2018). Does innovation make a difference? An analysis of the performance of micro and small enterprises in the foodservice industry in Brazil. Innovation \& Management Vol. 15 No. 2, 2018, 137-154.

Wang, C. L., \& Ahmed, P. K. (2007). Dynamic Capabilities: A Review and Research Agenda. The International Journal of Management Reviews, 9(1), 31-51.

World Economic Forum. (2015). Collaborative Innovation Transforming Business, Driving Growth. Cologny/Geneva: World Economic Forum. 